\title{
APRESENTAÇÃO
}

\section{Narrativas, Direitos Humanos e Formação de Professores de História}

Dossier Narratives, Human Rights and History Teachers Formation

Raquel ALS Venera*

Felipe Rodrigues da Silva ${ }^{\star *}$

Este Dossiê é uma afirmação das práticas narrativas e da visibilidade das reelaborações de memórias e seus usos no campo da pesquisa no ensino de História. Uma aposta na educação em e para os Direitos Humanos na formação de professores de História com intenções claras de defesa da república e da democracia. Trata-se de um dos resultados dos últimos estudos desenvolvidos no âmbito do Grupo de Pesquisa Subjetividades e (Auto)biografias da Universidade da Região de Joinville (UNIVILLE), que agora ampliamos e fortalecemos os diálogos com as produções científicas nacionais, contribuindo com as redes de estudos e pesquisas que compõem o campo do ensino de História.

A teorização da ligação orgânica entre narrativa, memória e história, mesmo não sendo um campo de estudos recente, permanece fundamental para os campos da História e da Educação, especialmente materializados no ensino de História. Se estes estudos por si só não são novidade, o Dossiê traz uma contribuição substancial para o ensino de História ao ampliar e diversificar as

\footnotetext{
*Universidade da Região de Joinville (UNIVILLE), Joinville, SC, Brasil. raquelsenavenera@gmail. com

** Secretaria de Educação, Joinville, SC, Brasil; Secretaria de Estado de Educação de Santa Catarina, Florianópolis, SC, Brasil.eh_felipe@yahoo.com.br
} 
possibilidades que as narrativas fornecem no campo em articulação com a formação e autoformação de professores de História.

Nesta perspectiva, os artigos aqui apresentados revelam as narrativas tais como as (auto)biografias de estudantes de licenciatura em História, as entrevistas com professores em formação continuada, as experiências de professores de História em formação e formadores e narrativas de professores experientes sobre conteúdos de conhecimentos históricos escolares inscritos em contextos de relevância social na medida em que se referem à educação, ensino da História e formação de professores em interface com os Direitos Humanos.

Socializamos estudos teóricos e resultados de pesquisas que exploram as mais diversas práticas narrativas e processos de aprendizagens e formação de professores de História, especialmente relacionados à educação para e em Direitos Humanos. Trata-se de uma perspectiva interdisciplinar no ensino de História que entende a necessidade de diálogos do campo da História com outras áreas do conhecimento, tendo em vista os problemas complexos da sociedade que se evidenciam nas salas de aula. Em específico, as questões urgentes relacionadas aos Direitos Humanos exigem dos professores a consciência reflexiva e dialógica entre os saberes experienciais e os acadêmicos.

Desta forma, os artigos focam discussões sobre experiências narrativas, formação e autoformação docente, especialmente aquelas relacionadas aos sentidos do tempo, da memória e dos Direitos Humanos. Destacam-se aspectos envolvidos na elaboração de memórias e modos como os sujeitos reconfiguram suas identidades no processo de aprendizagens formativas sistemáticas, como em universidades e cursos de formação, mas também em experiências do fazer docente, com colegas mais experientes, estudantes, comunidades, movimentos sociais.

Entendemos as identidades e os saberes docentes em suas mais diversas articulações, desde aqueles previstos nas diretrizes oficiais da formação, mas também da reflexividade das experiências cotidianas expressas em narrativas de memórias. Por isso, o Dossiê intencionou evidenciar discussões sobre pesquisas no ensino de História em suas dimensões epistemológicas interdisciplinares e de práticas narrativas como aposta ética e política da formação e valorização da vida e da construção existencial no tempo.

O artigo "Rios de Marielles: uma experiência de formação de professores/ as entre direitos humanos, patrimônio e cidade", que abre este Dossiê, revela- 
-nos resultados de uma pesquisa-ação na formação de professores de História. A partir da experiência de luto pelo assassinato da vereadora Marielle Franco, Carina Martins Costa trocou o planejamento previamente organizado e deu lugar ao ensino dos Direitos Humanos como eixo central de uma abordagem das memórias e esquecimentos em prol da defesa de igualdade de gênero, educação antirracista e direito à cidade.

Na mesma direção de defesa de igualdade racial e étnica, o artigo de Tanara Forte Furtado e Carla Beatriz Meunerz, intitulado "Formação continuada de professores e educação antirracista: ensino de história, africanidades e rompimento de estereotipias", versa sobre a formação de professores que atuam na Educação Infantil e anos iniciais do Ensino Fundamental. Busca compreender a implementação do ensino de História afro-brasileira como ação curricular afirmativa e constata a construção de estereotipias ao mesmo tempo em que desestabiliza identidades docentes na consolidação da Educação das Relações Étnico-Raciais nos espaços escolares.

No artigo "Direitos humanos e conteúdos de História: relações possíveis a partir das perspectivas de professores", a autora Fabrícia Vieira de Araújo ouve professores que atuam em escolas públicas, por meio de entrevistas semiabertas, e desvela conteúdos de História da Europa e Brasil que os professores evocam quando aproximam Direitos Humanos e História. Os assuntos ensinados sobre os passados são ligados ao presente por uma ponte construída pelos educadores em um trabalho em defesa das liberdades, das pluralidades culturais e em respeito às diferenças.

Edson Holanda Lima Barboza e Silviana Fernandes Mariz discutem o processo de construção e de implementação do curso de Licenciatura em História da Universidade da Integração Internacional da Lusofonia Afro-Brasileira (Unilab) na cidade de Redenção, no Ceará. Ao abordar a questão do currículo em seu artigo "Direitos humanos e currículo transnacional: os desafios da licenciatura em história da Unilab", os autores evidenciam as disputas por hegemonia que permeiam os documentos e práticas curriculares nos quais a licenciatura em História da Unilab se baseia e os territórios contestados nos quais este currículo se desenvolve, sobretudo no que se refere a ementas disciplinares que discutem temas caros aos Direitos Humanos, tais como as questões de raça, etnia, sexualidade, intolerância religiosa e os múltiplos movimentos sociais que lutam em favor destas questões, problematizando o desafio de tornar este 
currículo transnacional. Trata-se de um texto importante para pensar os desafios da formação de professores que atuarão no ensino de História.

O artigo "Conhecimento escolar sobre a Guerra do Paraguai: construção de significados e identidades, no Brasil e no Paraguai, no século XX”, desenvolvido por André Mendes Salles e José Batista Neto, empreende reflexões sobre as narrativas escolares a respeito do conflito na bacia do Prata, articulando narrativas de livros didáticos e de educadores brasileiros e paraguaios, desenvolvidas por meio de questionários e entrevistas, no sentido de pensar este conhecimento escolar como um recurso de memória capaz de produzir significados que promovam identificações com os estados nacionais envolvidos. $\mathrm{O}$ artigo também ajuda a desenvolver reflexões sobre Direitos Humanos a partir da guerra e da função social do ensino de História para a construção de uma cultura de paz.

O ateliê (auto)biográfico como uma ferramenta de pesquisa-formação de estudantes de licenciatura em História participantes do PIBID é a problemática desenvolvida por Felipe Rodrigues da Silva e Raquel Alvarenga Sena Venera no artigo "Ensino de História, Direitos Humanos e Narrativas: potencialidades da pesquisa-formação". Após revisitar as trajetórias da educação em e para os Direitos Humanos no Brasil com ênfase para o ensino de História, defende-se o ateliê como um recurso de pesquisa com potencial formativo a partir da reflexividade desenvolvida pelos atores participantes e, assim, com a capacidade de promover entendimentos e práticas relacionadas aos Direitos Humanos e contribuir com a formação para a docência no ensino de História.

Ao apresentar este leque de produções científicas que articulam Ensino de História, Direitos Humanos e Narrativas, desejamos que as leituras deste Dossiê contribuam para novas pesquisas e práticas interdisciplinares sobre o tema. Que inspirem a decisão de trazer as experiências de defesa da dignidade e da vida ao centro das investigações de produção heurística. 